\title{
Retail Investors' Preferences towards Investment in Mutual Funds
}

\author{
S. O. Junare, Vishal A. Acharya, Kiran J. Patel
}

\begin{abstract}
This research aims to study retail investors' preferences towards mutual funds from Gujarat perspective. For this, survey approach was used in order to solicit primary data from the respondents. The structure questionnaire was distributed among 325 respondents out of which 288 valid questionnaires were received with full response with 88.62 percent response rate. The survey was carried out in the month of August - September, 2019. The data were analyzed using SPSS version 20.

The results of this study indicated that majority people make investment with an objective of getting tax relief; there is association between: 1) occupation and kind of investments 2) occupation and mode of investments. The findings of this study provide valuable insights to mutual funds companies and govt. about which factors affects investors' investment decisions towards mutual funds. Moreover, investors can have ideas about what other investors think of about investment in mutual funds. The limitations of this study will create scope for further research in same domain in future.
\end{abstract}

Keywords: Customer Preference, India, Investor, Mutual Fund, Performance Level

\section{INTRODUCTION}

India is one of the fastest growing economies in the world with rising incomes, but also savings and investments. The liberalization and publication of a new industrial policy in 1991 enabled it to create an environment for the efficient allocation of resources among new entrants. The main sector of emerging financial markets is investment in mutual funds. The mutual fund sector plays a key role in the development of financial markets, business sector and growth of financial intermediaries. The regulatory measures to develop mutual fund industry and to protect the interests of MF investors are also important. This study sought to examine Indian mutual fund industry and compare their plans for presenting the behavior of mutual fund companies and investors.

\section{REVIEW OF LITERATURE}

The selection of mutual fund that gives high yield with minimum risks is a difficult task. As depicted by past literature, many factors have significant influence on the

Revised Manuscript Received on October 25, 2019

Dr. S. O. Junare, Professor and Dean, Faculty of Management, Gujarat Forensic Sciences University, Gandhinagar, Gujarat, India; Email Id: prof.junare@gfsu.edu.in

Prof. Vishal A. Acharya, Assistant Professor, V. M. Patel College of Management Studies, Ganpat University, Kherva, Gujarat, India; Email Id: vishal.acharya@ganpatuniversity.ac.in

Dr. Kiran J. Patel, Assistant Professor, V. M. Patel College of Management Studies, Ganpat University, Kherva, Gujarat, India; Email Id: kjp01@ganpatuniversity.ac.in mutual fund performance. There are some past studies (Bogle, 1992; Brown \&Goetzman, 1995) in which it was confirmed that there is somewhat positive association between past performance of mutual fund and its present returns. However, other past researches concluded that good relationship between past MF performance and its present returns (Grinblatt\& Titman, 1992; Hendricks et al., 1993).

There is inverse relationship between expense ratio and mutual fund performance (Elton et al., 1996; Carhart, 1997; Liljeblom \& Loflund, 2000). Ang et al. (1998), in their study, revealed that expenses increase when mutual fund managers follow active trading approach, since they would necessitate a big research team. As recommended by Golec (1996), retail investors should ignore such funds which have higher expense ratio. The mutual funds with less transaction cost perform extremely well than those with high transaction costs (Ippolito, 1989; Elton et al., 1993). However, there is a positive association between performance and expense ratio (Chen et al., 1992). Some prior studies confirmed an opposite association between size of mutual fund and its performance (Grinblatt \& Titman, 1989; Chen et al. 1992; Golec, 1996; Ang et al., 1998).

Furthermore, Bijan Roy et al. conducted an empirical study on conditional performance of Indian mutual funds. This paper uses a technique called conditional performance evaluation. This paper measures the performance of various mutual funds with both unconditional and conditional form of CAPM, Treynor-Mazuy model and Henriksson-Merton model. Mishra, et al., (2002) measured mutual fund performance using lower partial moment. In this paper, measures of evaluating portfolio performance based on lower partial moment are developed. Risk from the lower partial moment is measured by taking into account only those states in which return is below a pre-specified "target rate" like risk-free rate. Kshama Fernandes (2003) evaluated index fund implementation in India.

\subsection{Hypotheses Development}

Based on the review of literature pertaining to investors' preferences towards mutual funds, the following hypotheses are postulated:

H1: There is association between occupation \& kind of investments made by Indian investors.

$\mathrm{H} 2$ : There is association between occupation and mode of investments.

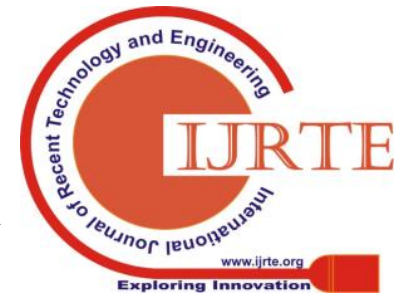




\section{RESEARCH METHODOLOGY}

3.1 Objectives of the Study

a) To analyze retail investors' preference towards mutual funds in India

b) To examine various aspects of mutual fund investment from investors' perspective viz. preferred investment, main influential factor in investment decision, popular mutual fund, type of funds and feature attracting investors for $\mathrm{MF}$ investment

c) To identify the key factor affecting retail investors' investment decision

\subsection{Research Procedure:}

This study is analytical in nature i.e. collection of primary data through structured questionnaire. The questionnaire was administered personally 325 Indian retail investors by following non-probability convenience sampling method, of which 288 valid questionnaires were processed and analysed for data analytical purpose. The review of literature was undertaken in order to identify key aspects of investors' preferences towards mutual fund investments. Moreover, interviews were held with retail investors to solicit their investment opinions. Pilot testing was carried out among 30 investors and minor modifications were done in final questionnaire accordingly.

3.3 Data Analytical Tools:

For data analysis, descriptive statistics (i.e. frequency, percentage and weightaged average) and chi-square test are applied using SPSS version 20.

\section{DATA ANALYSIS AND RESULTS}

\subsection{Demographic Profile of the Respondents}

Table I summarized demographic profile of surveyed respondents. Among them, 68.06 percent were male and 31.94 percent were female. Majority of them $(n=103,35.76$ percent) fall into the age bracket of 21-30 years, 35.07 percent $(n=101)$ in the age group of $31-40$ years. Moreover, 11.46 percent participants $(\mathrm{n}=33)$ were studied upto S.S.C., 15.97 percent $(n=46)$ H.S.C. and 40.97 percent $(n=118)$ had graduation degree indicating sample domination of educated people. With regard to respondents' monthly income, majority of them have income between Rs. 15,000 Rs. 25,000 ( $\mathrm{n}=106,36.81$ percent). Considering occupation variable, it is found that most of them are private sector employees $(\mathrm{n}=112)$ followed by public sector employees $(\mathrm{n}=$ $64)$ and businessman $(n=52)$.

Table I: Demographic Profile of the Respondents $(\mathrm{n}=288)$

\begin{tabular}{|c|l|c|c|}
\hline $\begin{array}{c}\text { Demographi } \\
\text { c Variable }\end{array}$ & \multicolumn{1}{|c|}{ Category } & $\begin{array}{c}\text { Frequenc } \\
\mathbf{y}\end{array}$ & $\begin{array}{c}\text { Percentag } \\
\text { e }\end{array}$ \\
\hline \multirow{2}{*}{ Gender } & Male & 196 & 68.06 \\
\cline { 2 - 4 } & Female & 92 & 31.94 \\
\hline \multirow{2}{*}{$\begin{array}{c}\text { Age } \\
\text { (in year) }\end{array}$} & $21-30$ & 103 & 35.76 \\
\cline { 2 - 4 } & $31-40$ & 101 & 35.07 \\
\hline
\end{tabular}

\subsection{Aspects of Mutual Fund Investment}

As mentioned in Table II, it is clearly seen that majority of Indian retail investors want safety of their investments. In this regard, saving account, mutual funds, mutual funds, insurance and fixed deposit account are the most preferred investment avenues for Indian investors. However, they give least priority to real estate as an investment option. Moreover, low risk is the key factor affecting their investment decisions followed by other factors in order of their influence viz. high return, liquidity and trust. Thus, it can be concluded that most of them are not ready to take high risk but demand high returns on their investments.

Considering popular MF, there is no much difference in popularity of mutual funds. Almost all mutual funds are equally popular. Among Indian retail investors, most favourable is SBI MF followed by IDBI MF and Reliance MF. From surveyed respondents, only 20.83 percent $(n=60)$ wants to make their investment in equity related MF revealing their high risk taking capacity whereas 20.14 percent $(n=58)$ prefer to make investments in their debt related MF due to their less risk taking capacity with expectation of secured returns. However, approximately 60 percent $(n=170)$ people prefer such type of mutual fund schemes which have debt and equity portfolio. Besides this, majority of the respondents are 
attracted by risk reduction feature $(n=115)$. This is the reason why they are investing in mutual funds which is followed by other factors viz. diversification, long-term goals achievement and professional management.

Table II: Aspects of Mutual Fund Investment $(n=288)$

\begin{tabular}{|c|c|c|c|}
\hline $\begin{array}{c}\text { Aspect of MF } \\
\text { Investment }\end{array}$ & Category & Frequency & Percentage \\
\hline \multirow{8}{*}{$\begin{array}{l}\text { Preferred } \\
\text { Investment } \\
\text { (any one) }\end{array}$} & Saving Account & 66 & 22.92 \\
\hline & Fixed Deposit Account & 37 & 12.85 \\
\hline & Insurance & 45 & 15.63 \\
\hline & Mutual Funds & 61 & 21.18 \\
\hline & $\begin{array}{l}\text { Post-Office Savings } \\
\text { Account }\end{array}$ & 29 & 10.07 \\
\hline & Share / Debentures & 32 & 11.11 \\
\hline & Gold \& Silver & 13 & 4.51 \\
\hline & Real Estate & 5 & 1.74 \\
\hline \multirow{4}{*}{$\begin{array}{c}\text { Main Influential } \\
\text { Factor in } \\
\text { Investment } \\
\text { Decision }\end{array}$} & Low Risk & 104 & 36.11 \\
\hline & Liquidity & 58 & 20.14 \\
\hline & High Return & 92 & 31.94 \\
\hline & Trust & 34 & 11.81 \\
\hline \multirow{6}{*}{$\begin{array}{l}\text { Popular Mutual } \\
\text { Fund }\end{array}$} & SBI MF & 78 & 27.08 \\
\hline & $\begin{array}{l}\text { UTI MF } \\
\end{array}$ & 27 & 9.38 \\
\hline & HDFC MF & 40 & 13.89 \\
\hline & Reliance MF & 56 & 19.44 \\
\hline & Kotak MF & 26 & 9.03 \\
\hline & IDBI MF & 61 & 21.18 \\
\hline \multirow{3}{*}{ Type of Funds } & Only Equity Portfolio & 60 & 20.83 \\
\hline & Only Debt Portfolio & 58 & 20.14 \\
\hline & $\begin{array}{l}\text { Debt and Equity } \\
\text { Portfolio }\end{array}$ & 170 & 59.03 \\
\hline \multirow{4}{*}{$\begin{array}{c}\text { Feature Attracting } \\
\text { Investors for MF } \\
\text { Investment }\end{array}$} & Diversification & 104 & 36.11 \\
\hline & $\begin{array}{l}\text { Professional } \\
\text { Management }\end{array}$ & 26 & 9.03 \\
\hline & Reduction in Risk & 115 & 39.93 \\
\hline & $\begin{array}{ll}\text { Long-Term } & \text { Goals } \\
\text { Achievement } & \end{array}$ & 43 & 14.93 \\
\hline
\end{tabular}

\subsection{Rank Analysis}

Factors Affecting Investors' Investment Decision

Table III: Factors Affecting Investors' Investment Decision

\begin{tabular}{|l|c|c|c|c|c|c|c|}
\hline $\begin{array}{c}\text { Factors Affecting } \\
\text { Investment Decision }\end{array}$ & $\mathbf{1}$ & $\mathbf{2}$ & $\mathbf{3}$ & $\mathbf{4}$ & $\mathbf{5}$ & $\begin{array}{c}\text { Weighted } \\
\text { Average }\end{array}$ & Rank \\
\hline Security of original capital & 69 & 66 & 57 & 42 & 54 & 3.19 & 4 \\
\hline Wealth accumulation & 24 & 43 & 59 & 62 & 100 & 2.41 & 9 \\
\hline Comfort factor & 51 & 42 & 38 & 72 & 85 & 2.66 & 7 \\
\hline Tax efficiency & 92 & 87 & 63 & 31 & 15 & 3.73 & 1 \\
\hline Life cover & 60 & 46 & 72 & 67 & 43 & 3.05 & 5 \\
\hline Income & 46 & 67 & 91 & 76 & 8 & 3.23 & 2 \\
\hline Simplicity & 43 & 49 & 54 & 61 & 81 & 2.69 & 6 \\
\hline Communication & 38 & 34 & 46 & 92 & 78 & 2.52 & 8 \\
\hline Ease of withdrawal & 78 & 56 & 47 & 62 & 45 & 3.21 & 3 \\
\hline
\end{tabular}

As summarized in Table III, it can be noticed that the main factor affecting investors' investment decision is tax efficiency i.e. majority people make investment with an objective of getting tax relief. In addition, second affecting factor is income generation which is followed by ease of withdrawal (i.e. investors want liquidity in terms of withdrawing their money whenever they need the fund(s), security of original capital, life cover, simplicity, comfort, communication and wealth accumulation.

\section{Investors' Preference for Mutual Fund Company}

Table IV: Investors' Preference for Mutual Fund Companies

\begin{tabular}{|l|c|c|c|c|c|c|c|c|c|}
\hline $\begin{array}{c}\text { Investors, } \\
\text { Preference for } \\
\text { MF Company }\end{array}$ & $\mathbf{1}$ & $\mathbf{2}$ & $\mathbf{3}$ & $\mathbf{4}$ & $\mathbf{5}$ & $\mathbf{6}$ & $\mathbf{7}$ & $\begin{array}{c}\text { Weigh } \\
\text { ted } \\
\text { Avera } \\
\text { ge }\end{array}$ & $\begin{array}{c}\text { Ra } \\
\mathbf{n k}\end{array}$ \\
\hline Reliance MF & 58 & 49 & 61 & 49 & 28 & 25 & 18 & 4.70 & 3 \\
\hline ICICI Prudential & 8 & 14 & 11 & 92 & 87 & 42 & 34 & 3.27 & 5 \\
\hline Kotak & 62 & 78 & 64 & 27 & 21 & 19 & 17 & 5.03 & 2 \\
\hline UTI & 15 & 9 & 24 & 32 & 41 & 75 & 92 & 2.68 & 7 \\
\hline HDFC & 10 & 13 & 38 & 44 & 41 & 58 & 84 & 2.91 & 6 \\
\hline SBI & 84 & 61 & 72 & 27 & 14 & 19 & 11 & 5.25 & 1 \\
\hline IDBI & 51 & 64 & 18 & 17 & 56 & 50 & 32 & 4.16 & 4 \\
\hline
\end{tabular}

Investors were asked about which mutual fund company come first in their mind while they think about investment in mutual funds. From the result of company wise weighted average, it can be said that SBI comes first in investors' mind when they think about mutual fund investment which are followed by certain other mutual fund companies in order of rank given by them for investment namely Kotak, Reliance MF, IDBI, ICICI Prudential, HDFC and UTI. So that from this data it can be concluded that these are the schemes which are most popular among investors (refer Table IV).

\subsection{Hypotheses Testing Results}

H1: There is association between occupation \&kind of investments made by Indian investors.

Table V: Chi-Square Test

(Association between occupation and kind of investments)

\begin{tabular}{|l|c|c|c|}
\hline & Value & df & $\begin{array}{c}\text { Sig. } \\
\text { Value }\end{array}$ \\
\hline Pearson Chi-Square & 48.268931 & 5 & 0.00 \\
\hline Likelihood Ratio & 60.33341 & 5 & 0.01 \\
\hline $\begin{array}{l}\text { Linear-by-Linear } \\
\text { Association }\end{array}$ & 5.313082 & 1 & 0.02 \\
\hline
\end{tabular}

a. 2 cells (16.7\%) have expected count less than 5.

\section{The minimum expected count is 4.70 .}

From Table V, it can be said that the result of chi-square test is significant $(\mathrm{p}=0.00<0.05)$ and therefore, $\mathrm{H} 1$ is found to be supported, indicating that there is association between occupation and kind of investments made by Indian retail investors. 
$\mathrm{H} 2$ : There is association between occupation and mode of investments.

Table VI: Chi-Square Test

(Association between occupation and mode of investments)

\begin{tabular}{|l|c|c|c|}
\hline & Value & df & $\begin{array}{c}\text { Sig. } \\
\text { Value }\end{array}$ \\
\hline Pearson Chi-Square & $\begin{array}{c}12.980 \\
\mathrm{a}\end{array}$ & 5 & 0.024 \\
\hline Likelihood Ratio & 19.758 & 5 & 0.001 \\
\hline $\begin{array}{l}\text { Linear-by-Linear } \\
\text { Association }\end{array}$ & 8.92 & 1 & 0.003 \\
\hline
\end{tabular}

a. 4 cells (33.3\%) have expected count less

than 5.

\section{The minimum expected count is 1.22.}

As given in Table VI, it can be observed that the result of chi-square test is significant $(\mathrm{p}=0.024<0.05)$ and therefore, $\mathrm{H} 2$ is found to be supported, confirming that there is association between occupation and mode of investments made by Indian retail investors. In nutshell, it can be interpreted that there exists relationship between occupation and mode of investments.

\section{CONCLUSION}

The present study highlighted that the level of awareness about investment in mutual funds as one of the investment avenues is very less in Indian investors specifically in rural areas. The people are not aware of the advantage that they can get by investing in mutual funds nor are they aware of the basic functioning of mutual funds. In India, people prefer to invest in govt. securities and term deposits although they earn less. People with high risk taking capacity can usually invest in equity markets, gold and real estate, etc. The getting services of financial advisor for fund management are expensive and that's why, some people choose financial advisers for effective administration of their funds' investments. Normally, Indian investors refer past history of particular mutual fund(s) for making small investments in specific scheme(s) which is not a valid method for evaluating fund's performance.

Normally, people expect high returns from their investment, but their readiness to take high risk is not high against their expectations. The finding of this study revealed that only 18 percent investors are ready to take high risk to get high returns whereas remaining 82 percent were not reluctant to take high risk though they were also expecting high return.

6. Limitations and Scope for Future Researches

The research is just a small step in understanding the constructs Customer preference and awareness. The causal

relationships have not been investigated. The present study is based on a small sample size and area covered is Gujarat state only, therefore the results of this study cannot be generalized to other states of India. However, this study provides an opportunity for the researchers to use larger sample size and arrive at generalization. The sample is Gujarat focused; the participants in this study may possess attributes and behavior that may differ from those in other parts of state.

Mutual Fund is such as a wide area of research that no single study can cover different dimensions related to it. Even primary surveys for studying the perceptions of investors towards mutual funds time to time is not a regular feature in India, Hence there is much potential of research on a bigger scale covering wider area. The future researcher could make several extensions of the current study by studying perception of institutional investors towards mutual funds. Future research could examine a wider respondent base across the different states of India with more diversified sample and can increase the number of respondents in the research.

\section{REFERENCES}

[1]. Berkowitz, M. K. and Kotowitz, Y. (2000), 'Investor risk evaluation in the determination of management incentives in the mutual fund industry', Journal of Financial Markets 3, 365-387.

[2]. Bruce A. Humnan, Nalinaksha Bhattacharyya (2005), "Does mutual fund Advertising provide necessary information? ".International Journal of Bank Marketing Vol. 23, No. 4, 2005, pp. 296-316.

[3]. Chen, H. and Pennacchi, G. G. (1999), 'Does prior performance affect a mutual fund's choice of risk? Theory and further empirical evidence', Working paper, University of Illinois.

[4]. Chevalier, J. and Ellison, G. (1997), 'Risk taking by mutual funds as a response to incentives', Journal of Political Economy 105, 1167-1200.

[5]. Chevalier, J., and G. Ellison, 1997.Risk Taking by Mutual Funds as a Response to Incentives. Journal of Political Economy 105:1167-200.

[6]. Chordia, T. (1996), "The structure of mutual fund charges", Journal of Financial Economics, Vol. 41 No. 1, pp. 3-39.

[7]. Comer, G. 2006.Hybrid Mutual Funds and Market Timing Performance. Journal of Business 79:771-97.

[8]. Elton, E. J., Gruber, M. J., and Blake, C.R. (1996), 'Survivorship bias and mutual fund performance', The Review of Financial Studies 9, 1097-1120.

[9]. Goetzmann, W.N. and Peles, N. (1997), "Cognitive dissonance and mutual fund investors", Journal of Financial Research, Vol. 20 No. 2, pp. 145-58.

[10]. Goetzmann, W.N., Massa, M. and Rouwenhorst, K.G. (2000), "Behavioural factors in mutual fund flows", working paper, Yale School of Management, New Haven, CT.

[11]. Graceila L. Kaminsky, Richard k. Lyons, Sergio 1. Schmukler (2001), "Mutual fund investment in emerging markets : An overview" The world bank economy review, Vol. 15, No. 2, pp 315-340.

[12]. Jaspal Singh; Subhash Chander (2004). "An Empirical Analysis of Perceptions of Investors towards Mutual Funds . Finance India. Vol. XVIII No. 4, December 2004, pp. 1673-1692.

[13]. Jiaping qui ( 2003). "Termination Risk, Multiple Managers and Mutual Fund Tournaments".Journal of European Finance Review 7. April 2003, pp. 161-190.

[14]. K.D. Mehru (2004), "Problems of mutual funds in India." Finance India. Volume XVIII No.1, March 2004, pp. 220 - 224.

[15]. Kothari, S. P., and J. Warner. 2001. Evaluating Mutual Fund Performance. Journal of Finance 49:1985-2010.

[16]. MarcinKacperczyk, Clemens Sialm, Lu Zheng, (2006), “ Unobserved actions of mutual funds", The oxford university press, October 25, 2006.

[17]. Maria do ceucortez and Florindasilva (2002), "Conditioning information on portfolio performance evaluation : A re-examination of performance persistence in the Portuguese mutual fund market” Finance India. Vol. XVI No.4, December 2002, pp. 1393- 1408. 
[18]. Ramesh Chandar (2002), "An evolution of portfolio performance components Across fund characterstics." Finance India, Volume XVI No. 4, December 2002, pp. 1377-1391.

[19]. Sirri, E. R., and P. Tufano (1998).Costly Search and Mutual Fund Flows. Journal of Finance 53:1589-622.

[20]. Tapan k. Panda, Nalinipravatripathy (2002). "An application of multiple dimension scaling model towards brand positioning of mutual funds : A case study of Tax saving scheme". Finance India. Volume XVI No.3, September 2002, pp. $991-1003$.

[21]. Treynor, J., and K. Mazuy. 1966. Can Mutual Funds Outguess the Market? Harvard Business Review 131-36.

[22]. Tufano, P., and M. Sevick (1997). Board Structure and Fee-Setting in the U.S. Mutual Fund Industry. Journal of Financial Economics 46:321-55.

[23]. Yong Bao (2009). "Estimation Risk-Adjusted Sharpe Ratio and Fund Performance Ranking under a General Return Distribution" Journal of finance econometrics 2009, Vol. 7, No.2, pp. 152-173. 